\title{
PEMANFAATAN SAMPAH SAYURAN RUMAH TANGGA MENJADI PELET PAKAN IKAN LELE (CLARIAS GARIEPINUS)
}

Dimas Putra Pratama*, Iva Rustanti Eri W, Ngadino

Jurusan Kesehatan Lingkungan Poltekkes Kemenkes Surabaya

*Email korespondensi: dimas.17putra@gmail.com

\begin{abstract}
Vegetable waste that is not utilized causes an unpleasant odor effect and disturbs the aesthetics of the environment, wet waste thrown away can become a breeding ground for insects. One of the waste utilization methods is the manufacture of fish pellets. The purpose of this study is to utilize household vegetable waste used for fish feed pellets.

The research design used was a pre-experimental design with a posttest only research design. The object of this research is vegetable waste originating from household activities. The treatments used were 3 variations of vegetables $(20 \%, 30 \%, 40 \%)$ repetition which was carried out 3 times with a concentration of $1 \mathrm{~kg}$. Making fish pellets using a machine that has been modified as a supporting tool for making pellets. The pellets produced were subjected to laboratory tests to determine the water content, ash content, fat content, crude fiber content, protein content referring to SNI (01-4087-2006) concerning catfish feed regulations.

The results showed that from variation $1(20 \%)$, variation $2(30 \%)$ and variation 3 $(40 \%)$ none of them met the Indonesian National Standard with water content, ash content, fat content, and protein content. crude fiber still does not meet because it is still under the provisions of SNI.

It was concluded that there were no pellets made from vegetable waste that met the stipulation value of SNI. The percentage that can be reviewed for the formulation is that the percentage of shrimp head flour can be increased to $20 \%$ and the fine bran can be reduced to $40 \%$. For the community, it can be useful to overcome the problem of vegetable waste being dumped directly into the surrounding environment without any processing of the vegetable waste to be used as fish feed pellets.
\end{abstract}

Keywords: Vegetable waste, fish feed pellets

\section{PENDAHULUAN}

Besarnya penduduk dan beragamnya aktivitas masyarakat di kota metropolitan Indonesia, menyebabkan timbulnya persoalan dalam pelayanan prasarana perkotaan, seperti permasalahan sampah dengan jumlah $90 \%$ dari keseluruhan produksi sampah yang ada di Indonesia belum mengalami proses daur ulang. Setiap hari produksi sampah di kawasan metropolitan mencapai 2.000 hingga 6.000 ton (Sucipto 2012). Total sampah yang ada di kota besar merupakan sampah organik sebesar $70 \%$ dan sampah anorganik sebesar 28\%. (Damanhuri 2010) Pada era global seperti ini, jumlah penduduk mengalami peningkatan yang cukup pesat serta di iringi dengan pola konsumsi masyarakat yang turut meningkat, sehingga menimbulkan berbagai jenis sampah. Sampah merupakan sisa dari suatu kegiatan manusia yang sudah terpakai, tidak di senangi dan harus di buang yang berbentuk padat.(Notoatmodjo 2007). Sampah merupakan salah satu penyebab rusaknya lingkungan hidup yang sampai saat ini masih menjadi masalah yang besar, dimana dampak negatif yang ditimbulkan oleh sampah selain menurunkan higienitas dan kualitas lingkungan (Hartono 2008). Sumber sampah organik merupakan sampah yang terdiri dari sampah dapur rumah tangga, sisa makanan, kulit buah dan sampah taman, yang mudah hancur dan terurai secara alami, sampah organik mengalami pembusukan atau penguraian oleh mikroba atau jasad renik seperti bakteri, jamur dan sebagainya. Pada proses penguraian tersebut dibutuhkan kondisi lingkungan yang optimal agar semakin cepat atau semakin baik mutu komposnya (Ardiningtyas 2013). Sampah basah yang dibuang begitu saja dapat menjadi tempat 
perindukan serangga yaitu lalat, Dimana tempat perindukan lalat tersebut berada di TPS, sehingga populasinya sangat padat serta perlu pengamatan dan pengendalian. indikator kepadatan lalat merupakan cara untuk mengetahui keberhasilan dalam pengelolaan sampah.

Sampah sayuran yang sampai saat ini merupakan bahan yang sudah tidak dimanfaatkan atau dibuang secara langsung tanpa ada pengelolahan lebih lanjut,sehingga timbul efek bau yang tidak sedap dan menggangu estetika lingkungan. Kandungan protein kasar pada sampah sayuran sebesar 12,64$23.50 \%$ dan kandungan serat kasar 20,76 -29,18\%(Muktiani et al., 2007). Menurut Undang-Undang nomor 18 tahun 2008 setiap orang dalam pengelolaan sampah rumah tangga dan sampah sejenis sampah rumah tangga wajib mengurangi dan menangani sampah dengan cara yang berwawasan lingkungan.(Per UU No 18 Tahun 2008) Teknologi pemanfaatan sampah organik diantaranya adalah pengomposan, menurut Faatih (2012) pengomposan merupakan salah satu metode yang digunakan untuk mengolah limbah organik menjadi bentuk material baru yang menyerupai tanah/humus. Widyaningrum (2017) menyatakan bahwa Salah satu teknologi dalam pemanfaatan sampah adalah biogas dapat menghasilkan sumber bahan bakar alternatif yang dapat diperbaharui karena menggunakan bahan baku yang berasal dari kotoran ternak, sampah organik / sampah sayur. Teknologi lain dalam pemanfaatan sampah adalah pembuatan pelet untuk pakan hewan. Pelet merupakan suatu pakan ternak yang terbuat dari beberapa macam bahan yang di campur dan dijadikan menyerupai bentuk adonan, yang kemudian dicetak dengan bentuk mirip batang atau bulatan kecil-kecil dengan variasi ukuran tertentu yang berbentuk sudah padat dan kering Setyono (2012). Teknologi pemanfaatan sampah dengan cara ini masih jarang dilakukan oleh masyarakat di bandingkan dengan teknologi komposting dan biogas. Ikan lele merupakan salah satu komoditas perikanan air tawar yang banyak dibudidayakan di Indonesia karena permintaannya terus meningkat setiap tahunnya. Untuk memenuhi kebutuhan masyarakat yang terus meningkat, sehingga diperlukan peningkatan intensifikasi usaha budidaya didukung oleh adanya ketersediaan benih yang memadai (Shafrudin and Setiawati 2006) Menurut Siska et al.,(2016) menyatakan bahwa kandungan protein pelet ikan yang berasal dari sampah sisa makanan sebesar 32\% dan kandungan protein pelet dari sampah ikan sebesar 59,02\%. Menurut Dewi et al.,(2016) pelet ikan lele berasal dari campuran ampas tahu dan sampah kepala udang menghasilkan kadar protein sebesar 43,05\% dan kadar lemak 25,50\%. Menurut Sunardiyanto et al.,(2016) Menerangkan bahwa pelet ikan yang berasal dari tepung kedelai mengandung protein kasar $30.88 \%$, serat kasar $10.35 \%$, dan kandungan kadar air $10.93 \%$. Tujuan penelitian ini adalah pemanfaatan sampah sayuran rumah tangga menjadi pelet pakan ikan lele (Clarias Gariepinus).

\section{METODE PENELITIAN}

Disain penelitian yang digunakan dalam penelitian ini adalah rancangan praeksperimen dengan design penelitian posttest only design. Obyek penelitian yang diambil dalam penelitian ini adalah sampah organik sayuran yang berasal dari kegiatan rumah tangga yang mana akan digunakan sebagai bahan baku utama pembuatan pelet ikan. Variabel penelitian ini yaitu sampah organik, kandungan kadar air, kadar abu, kadar lemak, kadar serat kasar, kadar protein yang terkandung pada pelet ikan. Analisis data yang diambil dari penelitian ini adalah data dari hasil pemeriksaan laboratorium kemudian di bentuk diagram batang dan di sajikan dalam bentuk persentase kemudian di analisa secara deskriptif dengan berpedoman pada (SNI 01-40872006).

Alat yang digunakan untuk pembuatan pelet pakan ikan yaitu timbangan untuk menimbang bahan baku pembuatan pelet ikan, alat modifikasi pembuatan pelet, loyang digunakan untuk mengeringkan pelet, oven alat untuk mengeringkan pelet tanpa di jemur. Bahan yang dibutuhkan adalah Sampah sayuran, Tepung kepala udang (Bahan Hewani), Dedak halus 
(Bahan Nabati), Tepung kanji (Bahan Perekat), Vitamin Mix, dan Air.

Langkah kerja pembuatan pellet sebagai berikut: Siapkan semua bahan yang dibutuhkan untuk pembuatan pelet ikan yang berbahan baku sampah sayuran sesuai perbandingan dan bahan pelengkap lainya yang sesuai dengan takaran. Menimbang bahan baku yang sesuai dengan takaran. Masukkan sampah organik kedalam mesin pencacah. Masukkan dan campurkan tepung udang, dedak halus, kedalam mesin pengaduk kemudian tambahkan vitamin mix. Setelah bahan tercampur rata masukkan sedikit demi sedikit tepung kanji yang telah dicampur dengan air panas sebagai perekat. Tambahkan air apabila adonan kurang basah atau terlalu kering. Setelah adonan dirasa mencapai kepadatan yang ideal masukkan kedalam mesin pencetak pelet. Keringkan dengan menggunakan oven, atau juga dapat di jemur menggunakan sinar matahari. Pelet siap digunakan sebagai pakan ikan. Pengulangan sebanyak 3 kali.

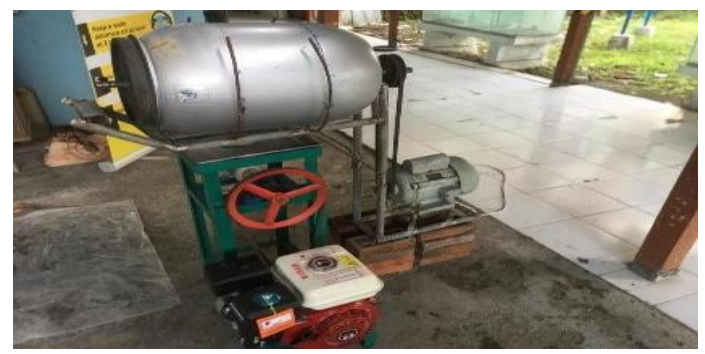

Gambar 1

Rancangan alat modifikasi mesin pembuat pelet pakan ikan

\section{HASIL DAN PEMBAHASAN}

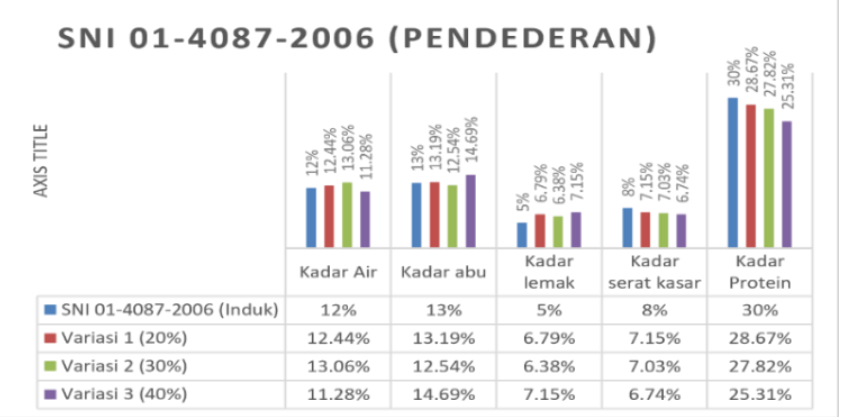

Gambar 2

Diagram Batang Perbandingan SNI Pendederan Dengan Varisasi Sampah Sayuran 20\%,30\%,40\%

Berdasarkan gambar diagram batang dapat diketahui bahwa variasi 1 semua variabel memenuhi persyaratan SNI kecuali variabel pada kadar protein yang hanya memiliki presentase $28,67 \%$. Pada variasi 2 variabel yang kurang memenuhi syarat SNI adalah variabel Kadar Abu yang memiliki presentase sebesar $12,54 \%$ dan kadar protein yang hanya memiliki presentase $27,82 \%$. Sedangkan pada variasi 3 variabel yang kurang memenuhi syarat SNI adalah kadar air dengan presentase $11,28 \%$ dan kadar protein yang memiliki presentase $25,31 \%$. Menurut Rina Iskandar (2017), Abu total didefinisikan sebagai residu yang dihasilkan pada proses pembakaran bahan organik, berupa senyawa anorganik dalam bentuk oksida, garam dan juga mineral. Abu total yang terkandung di dalam suatu produk dibatasi jumlahnya. Protein merupakan sumber energi utama pada ikan, jika kebutuhan protein tidak dicukupi dalam makanannya maka akan terjadi penurunan drastis atau penghentian 
pertumbuhan atau kehilangan bobot tubuh karena ikan akan menarik kembali protein dari beberapa jaringan untuk mempertahankan fungsi dari jaringan yang lebih vital.

Menurut Winarno (2004), kandungan Kadar Air yang memiliki kadar air terlalu tinggi kurang menguntungkan karena mudah ditumbuhi mikroba dan disukai serangga. Kadar air yang ideal untuk pakan kurang dari $14 \%$, hal ini menunjukkan pakan uji memiliki kualitas yang baik. Kandungan air mutlak diperlukan, akan tetapi dalam jumlah sedikit. Kelebihan air dalam pakan dapat menyebabkan pakan mudah rusak.

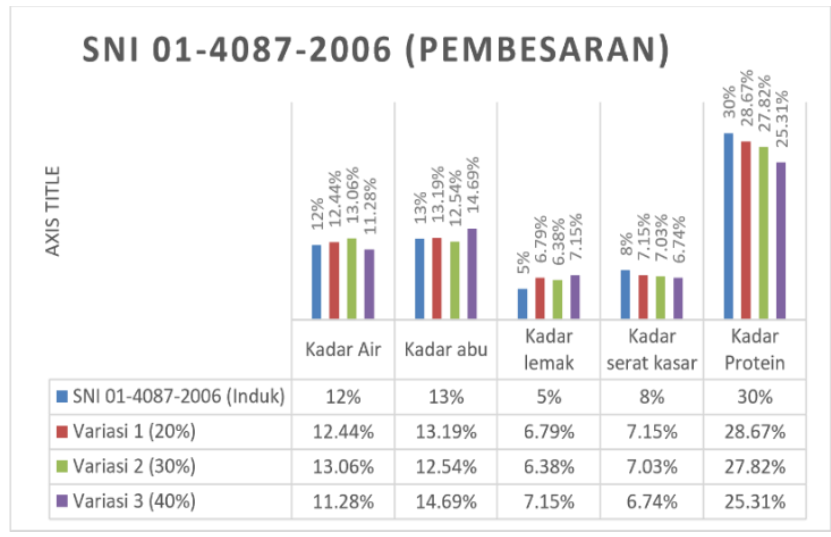

Gambar 3

Diagram Batang Perbandingan SNI Pembesaran

Dengan Varisasi Sampah Sayuran 20\%,30\%,40\%

Berdasarkan gambar diagram batang dapat diketahui bahwa pada variasi 1 semua variabel memenui syarat SNI kecuali kadar serat kasar dengan presentase 7,15\%. Pada variasi 2 variabel yang kurang memenuhi SNI adalah kadar abu yang memiliki presentase $12,54 \%$ dan kadar serat kasar yang memiliki presentase $7,03 \%$. Sedangkan pada variasi 3 variabel yang tidak memenuhi adalah kadar air dengan presentase $11,28 \%$ dan kadar serat kasar yang memiliki presentase $6,74 \%$. Kelemahan penelitian ini yaitu bahwa kandungan Kadar Serat Kasar untuk ikan dalam masa pembesaran masih dibawah Standar Nasional indonesia karena Serat Kasar pada sampah sayuran yang rendah.
Evaluasi dari hasil penelitian bahwa pembuatan pelet pakan ikan harus memperhatikan dalam pemilihan bahan baku yang memiliki serat kasar yang cukup tinggi adar dapat memberikan kualitas pelet pakan buatan untuk ikan yang baik sesuai dengan Standar Nasional Indonesia 01-4087-2006. Pakan ikan yang baik dan bagus bagi ikan lele adalah pakan yang mengandung (kadar air, kadar abu, kadar lemak, kadar serat kasar, kadar protein) yang seimbang yang sesuai dengan pakan ikan. Kebutuhan kandungan tersebut harus sesuai dengan kebutuhan ikan agar sesuai dengan kebutuhan ikan agar pertumbuhan menjadi optimal. 


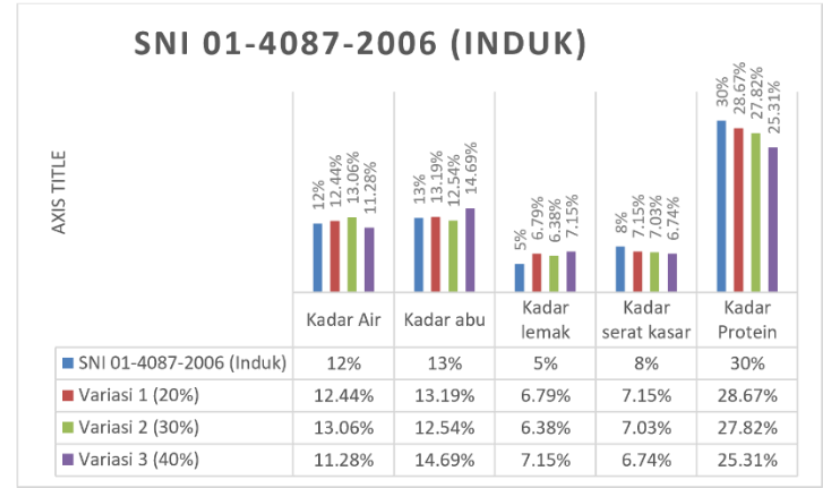

Gambar 4

Diagram Batang Perbandingan SNI Induk

Dengan Varisasi Sampah Sayuran 20\%,30\%,40\%

Berdasarkan gambar diagram batang dapat diketahui bahwa variasi 1 variabel yang kurang memenuhi syarat SNI yaitu pada variabel kadar serat kasar yang memiliki presentase $7,15 \%$, dan kadar protein yang memiliki presentase $28,67 \%$. Pada variasi 2 variabel yang kurang memenuhi syarat SNI adalah kadar serat kasar yang memiliki presentase $7,03 \%$, dan kadar protein $27,82 \%$. Sedangkan pada variasi 3 variabel yang kurang memenuhi syarat SNI adalah Kadar Air yang memiliki presentase $11,28 \%$, kadar serat kasar $6,74 \%$, dan Kadar Protein yang memiliki presentase $25,31 \%$. Berdasarkan penelitian yang dilakukan oleh Dewi et al., (2016)

"Pemanfaatan Ampas Tahu Sebagai Pakan Ikan Lele (Clarias Batrachus) Organik" mengemukakan bahwa dari hasil olahan Ampas Tahu yang dijadikan pelet pakan ikan organi menunjukkan kadar nutrien yang scukup tinggi yaitu pada perlakuan 1 yang menggunakan Ampas tahu (80\% dan Kepala Ikan 20\%) mendapatkan hasil protein $(42,01 \%)$, perlakuan 2 menggunakan (Ampas tahu $80 \%$ dan Kepala udang $20 \%$ ) mendapatkan hasil protein $(43,05 \%)$ dan pada perlakuan ke 3 menggunakan (Ampas tahu $50 \%$ dan Bekatul 50\%) mendapatkan hasil protein $(27,85 \%)$. Penambahan bahan seperti tepung tapioka dan bekatul juga mengansumsikan nilai protein dan karbohidrat pakan olahan menjadi lebih tinggi. Hal ini menunjukkan bahwa kandungan pelet pakan buatan untuk ikan dengan komposisi yang berbeda- beda belum ada yang memenuhi persyaratan untuk SNI. Dikarenakan kandungan kadar air, kadar lemak, kadar abu, kadar serat kasar dan kadar protein belum ada yang memenuhi. Karena di penelitian ini ada variasi yang menggunakan sampah sayuran. Maka sisa sampah sayuran lebih baik di jadikan tepung terlebih dahulu untuk menambah kandungan seratnya. untuk menghindari kandungan air yang tinggi persentase dedak dapat aplikasikan ke tepung udang. menurut Dinas Perikanan penelitian-penelitian memiliki rentan untuk tepung udang $20 \mathrm{~g}-40 \mathrm{~g}$ dedak $10 \mathrm{~g}-40 \mathrm{~g}$.

\section{KESIMPULAN}

Pembuatan pelet pakan ikan yang di dibuat dengan 3 variasi dan berbahan utama sampah sayuran yang telah dianalisa laboratorium belum dapat memenuhi nilai persentase SNI 014087-2006 tentang Pembuatan Pakan Untuk Ikan Lele dalam masa pendederan, pembesaran, dan induk.

\section{SARAN}

Konsentrasi dedak perlu diturunkan menjadi $40 \%$ sedangkan konsentrasi tepung kepala udang dinaikkan menjadi $20 \%$ agar dapat menambah kandungan serat kasar, protein dan lemak yang cukup untuk menghasilkan pelet pakan ikan yang berkualitas baik dan sesuai dengan SNI yang sudah di tentukan.

\section{DAFTAR PUSTAKA}

Ardiningtyas, T R. 2013. "Pengaruh Penggunaan 
Microorganism 4 ( EM4 ) Dan Molase Terhadap Kualitas Kompos Dalam Pengomposan Sampah Organik." 4: 109.

Damanhuri, Tri Padmi dan Enri. 2010. Program Studi Teknik Lingkungan Institut Teknologi Bandung. Pengelolaan Sampah. Diktat Kuliah TL-3104.

Hartono, Rudi. 2008. Penanganan Dan Pengelolaan Sampah. Jakarta: Penebar Swadaya.

Muktiani, B.I.M. Tampoebolon, dan J. Achmadi. 2007. "Fermentabilitas Rumen Secara In Vitro Terhadap Sampah Sayur Yang Diolah." academia 1(32): 44-50.

Notoatmodjo, Soekidjo. 2007. Promosi Kesehatan Dan IImu Perilaku. Jakarta: Rineka Cipta.

Dewi Nur Anggraeni, and Rahmiati Rahmiati. 2016. "Pemanfaatan Ampas Tahu Sebagai Pakan Ikan Lele (Clariasbatrachus) Organik." Biogenesis: Jurnal Ilmiah Biologi 4(1): 53-57.

Rina Iskandar, Subhan Fitriadi. 2017. "Analisa Proksimat Pakan Hasil Olahan Pembudidaya Ikan Di Kabupaten Banjar Kalimantan Selatan." Fakultas Pertanian Universitas Achmad Yani, Banjarmasin,Indonesia 42(1): 123.

Setyono, Bagus. 2012. Pembuatan Pakan Buatan. Kepanjen, Malang: Unit Pengelola Air Tawar.

Shafrudin, D, and Yuniarti M Setiawati. 2006. "Produksi Pada Sistem
Budidaya Dengan Pengendalian Nitrogen Melalui Penambahan Tepung Terigu Effect of Rearing D Ensity of "D Umbo " Catfish ( Clarias Sp . ) Fry on Production in the Controlled Nitrogen Culture System by Adding Wheat Powder Ikan Lele Meru." Jurnal Akuakultur Indonesia 2: 137-47.

Siska Desti Rahayu, Demes Nurmayanti, Fitri Rokhmalia. 2016. "Pemanfaatan Limbah Ikan Dan Sisa Makanan Untuk Pelet Pakan Ikan Di Wisata Delta Fishing Sidoarjo." Jurnal gemma kesehatan lingkungan 14(3): 140-43.

SNI 01-4087-2006. "Pembuatan Pakan Buatan."

Sucipto. 2012. Teknik Pengolahan Daur Ulang Sampah. Yogyakarta: Gosyen Publishing.

Sunardiyanto, Eko, Sri Kumalaningsih, and Arie Febrianto Mulyadi. 2016. "Pengaruh Sibtitusi Tepung Kedelai Dengan Terfermentasi Terhadap Kualitas Kimia Pelet Lele." : 1-7.

Undang-Undang Republik Indoneesia No 18 Tahun 2008. "Pengelolaan Sampah."

Widyaningrum, Nuratri. 2017. "Produksi Biogas Melalui Pengumpanan Bersama (Co-Feeding) Limbah Cair Tapioka Dan Limbah Sayuran." In Program Pascasarjana Fakultas Teknologi Pertanian Universitas Gadjah Mada Yogyakarta,.

Winarno. 2004. Kimia Pangan Dan Gizi. Jakarta: Gramedia Pustaka Utama. 